\title{
The Required Competencies of the Middle Managers in Five-Hotel Industry: A Case Study of Five-Star Hotels in Phnom Penh, Cambodia
}

\author{
Samphors Chum \\ Public and Private Management at Graduate School of Public Administration (GSPA), \\ Burapha University, Thailand \\ samphorschum@gmail.com
}

\begin{abstract}
The required competencies are crucial needs for tomorrow's hospitality industry leader that wish to remain their competitive and challenges. Middle managers working in standard hotel accommodations play an important role to coordinate employees' activities and determine the steps to increase of service productivities in order to achieve guest satisfaction and organizational goals. The objectives of this study are to investigate the required competencies essential for the success of middle managers and also the obstacles they face in managing five-star hotels industry in Phnom Penh, Cambodia. In this study, researcher adapts mixed method approach by conducting quantitative approach and qualitative approach at the same time in order to gain perspectives from different types of data. In particular, mixed method model of Creswell (2009) is employed in this research. All the employees working in fivestar hotels in Phnom Penh were the targets of this research to confirm the required competencies of middle manager. The researcher contacted three five-star hotels to ask the permissions to conduct this study in advance. However, only two five-star hotels agree to participate in this study with the total population of 710 employees (410 employees from Sofitel Phnom Penh Phokeethra Spa and Resort; and 290 employees from the Raffle Holel Le Royal Phnom Penh). This calculation is in line with the formula of Yamane (1960), in which 373 samples selected from all departments are asked about the required competencies essential for five-star hotels' middle managers. In order to analyze the data from questionnaires, the researcher used descriptive statistic on frequencies, percentages, and average which was later used to calculate the value of Mean. After that, there was semi-structure interview using Behavioral Event Interview Outline (BEIs) to gain responses. After receiving the data from ten middle managers and three high level managers, a qualitative content analysis method including transcribing, coding, and interpreting was applied in order to figure out the required competencies for success of middle managers in five-star hotels and the obstacles they face in the management.
\end{abstract}

Keywords: Required Competencies, Self-Management, Strategic-Positioning, Implementation, Critical Thinking, Interpersonal, Communication, Leadership, Industry Knowledge, Perception, Five-Star hotel

\section{Introduction}

Cambodia tourism is one of the main sources in economic development after agriculture and the garment industry (CIA Fact book, 2011; Chheang, 2010). The most famous destination in term of cultural tourism in Cambodia is Angkor temples with its thousand-year-old temples, located in Siem Reap province, is the world cultural heritage. However, Phnom Penh, a capital of Cambodia, is also an increase of tourists visiting over there in propose of MICE (Meetings, Incentives, Conferences and Exhibitions), and historical tourism as Cambodia used to have a sad history in the past. Phnom Penh needs many investments as being the best opportunity for foreigners to absorb the big luck as called land of gold. Hotels and guesthouses are the main accommodation for tourists in Cambodia while hotels are popular among high and medium class tourist and package tour group (Chheang, 2011). Thus the demand of tourism accommodation needs many Cambodian and foreign labors to manage these hotel hospitalities. Indeed, the hotels also require middle managers who are effectively capable to manage both individual and team work in many standard hotel industries. Also, Burergermeister (1983) said that “Today's beginning hospitality manager needs a diversity of talents, skills and competencies to meet the experience of the hospitality". Moreover, 
managers have to control many staffs in order to achieve the organizational goals. The hotel industry would not function very well and would not achieve its goals without good leadership (Bartol, Mathew \& Martin, 2003).

Regarding to Cambodian hospitality condition of works are similarly to the other countries such as irregular working, low salary, job stress, lack of training, job motivation and satisfaction and poor relationship between staffs that need more competencies for develop in each department to better high productivities. As these reasons, it may affect the increasing of turnover and poor service quality. Increasing of consumer demand patterns in the hotels and restaurant require working conditions that are frequently characterized as unsocial and irregular working hours in form of split shifts, weekend shifts, night shifts, holiday period (Busquets, 2010). Cambodian labor hospitality requires too many qualified employees to take the responsibility. Cambodian governors also encourage local to make understanding and prepare to build capacity for Asian Economic Community (AEC) in 2015. At the launching of seminar on Dissemination and Implementation of the Mutual Recognition Arrangement on Tourism Professionals (MRATP) focused on 32 job titles based on Hotel Services and Travel Services divided into 6 divisions in 2015, the tourism professionals will be able to mobilize to work in Association of South-East Asia Nations (ASEAN) countries, Cambodia has to pay a great attention to human resource development and training particularly on skill labors which is needed for services sector. When middle managers fail to develop their people, low morale and high turnover are likely to follow while Oslen (1999) pointed out that the rise in employee turnover rate which is common situation has dramatically affected negatively on the service quality and profitability of the organization. The increased number of turnover due to the lack of the required competencies and other factors is the big concern issue in five-star hotels in Phnom Penh, Cambodia. Researcher has inspiration strongly to identify the required competencies needed for middle manager in standard five-star hotels. Importantly, because of the upcoming AEC in 2015 leading to the high demand of skill development for tourism and hospitality professional, researcher would like to find out the basic results to contribution to Cambodian human resource development so as to be able to compete with other neighbor countries in ASEAN.

\section{Research Objectives}

There are two main objectives of the study:

1. To investigate the required competencies essential for success five-star hotels' middle managers in Phnom Penh, Cambodia:

1.1. To study the required competencies important for five-star hotels' middle managers through the perception of employees working in five-star hotels in Phnom Penh.

1.2. To identify the required competencies for success of five-star hotels' middle managers through the perception of department managers and high level managers.

2. To identify the obstacles faced by middle managers in five-star hotels in Phnom Penh, Cambodia.

\section{Literature Review}

The strong growth of tourism in Cambodia represents significant foreign exchange earnings and employment opportunities. At the 
present the environment of Siem Reap is threatened and the construction and the hotel boom because of the huge of number of tourism accommodation. While the number of tourist is growing fast in Siem Reap and the Angkor sites, the number of visitors to Phnom Penh is getting lower and the average in Cambodia is getting shorter (Chheang, 2010). Phnom

Penh has been the capital since the French colonized Cambodia, and has become the country's economic centerby the tourists and such import historical resources where offers a very wide rage and variety of hotels and guesthouses. The number and quality of hotels in Cambodia have escalated considerably in the last few years with several international hotel brands now joining small guesthouses and local hotels in the major tourist areas.According to the website of (MOT, 2013) survey, accommodation in Phnom Penh categorize into eight categories such as hotel, resort, condo, apartment, villa, motel, quest house and lodge. There are 208 hotels in this capital, but only three places where are standardized as fivestar hotels which consists are (1) Raffle Hotel Le Royal; (2) Sofitel Phnom Penh Phokeethra\& (3) Intercontinental Phnom Penh.

Because of flux tourists in Phnom Penh in term of MICE and historical building, standard hotel industries are the main requirement for them. Accommodation facilities play an important role in tourism development. Therefore, the hotels require middle managers who are effectively capable to manage both individual and team work in many standard hotel industries. Oftentimes middle managers try to resolve contradictions between what top managers hope to achieve and what first line managers can actually do, however hospitality middle managers in some departments of organizational structure of five-star hotels still do not feel confidence what leadership competencies require to be a leader of department in order to achieve organization's goals or vision and move up in to be viewed as a successful manager.

\subsection{Theories and Concept}

Many scholars are seeking to understand the concept and practices of the required competencies essential for employees in order to manage in the organization which is relevant to concept of leadership, competencies, leadership competencies, talent management, human resource management and development, result-based management, management functions and also service business management. In the business world today, management is the process of working with people and resources effectively and efficiency to accomplish organizational goals. The fundamentals include the four traditional functions of management: planning, organizing, leading and controlling (Goodman, Fandt, Michlitch\& Lewis, 2007; and Bateman \& Snell, 2009). However, in order to increase of employee-centered behaviors, Ivancevich, Konopaske\& Matteson (2009) argued that managers should: (1) use rewards rather than punishments for reinforcing and modifying subordinates' behavior; (2) keep lines of communication open at all times and share information in a manner that contributes to building and maintaining trust; (3) listen to employees in order to feel that what they have to say matters; (4) try to obtain positive outcomes for subordinates (5) provide opportunities when possible for employees to accomplish personal career objectives; and (6) don't afraid to admit mistake. The employee competency construct can be traced back to an article by McClelland (1973), in which the author does not directly define the world competency, but uses the 
term as a "symbol for an alternative approach to traditional intelligence testing". The use of the term competency was popularized in the competent manager. Additionally, Boyatzis (1982) defines competency as "an underlying characteristic of a person which results in effective and/ or superior performance in a job". Then, Dulewicz, 1989, (cited in Cardy\&Sevarajan, 2006) identified a set of four clusters of competencies as important for middle managers which categorized such as (1) intellectual (e.g. strategic perspective, analysis, and judgments), (2) interpersonal (e.g. persuasiveness, decisiveness), (3) adaptability (e.g. resilience), and (4) results orientation (e.g. initiative, business sense). A leader is responsible for motivating, facilitating, and encouraging their staffs to achieve common goal. Schermmerhorn (1999); and Hersey, Blancard\&Johson (2001) believed that the leading is a process used to motivate and to influence others to work hard to realizes and support organizational goal. It can be a planning tool for Human Resource Management (HRM) (McCartney \&Garrow, 2006; Cappell, 2008; and Kehinde, 2012). As McLagan (1989) identified HRD is an essential for training and development in term of coaching, career development, team building, and organization development as HRD is a part of a larger HRM department. Almost of HRD program focus on improving and renewing the knowledge, Skills, and Abilities (KSAs) of employees who should be more successful than new employees who don't have those same characteristics. Last but not least, information technology is a crucial competency important for employees nowadays. Crosby (2008) identified that Business Service Management (BSM) is a set of management software tools, processes and methods to manage IT via a business-center approach.

\subsection{Competencies in Hotel Industries}

The hospitality industry will have to face up to both present and future competition resulting from globalization, technological, and market change in order to remain competitive. To achieve this, organizations make changes to their structure strategies, work systems and management. Related to hotel management competencies,

Tas (1983, p. 60) identified the most important competencies for hotel manager trainees as: (1) managing guest problems with understanding and sensitivity; (2) maintaining professional and ethical standard in the work environment; (3) demonstrating poise and a professional appearance ; (4) communicating effectively both in writing and orally; (5) developing positive customer relations; and (6) striving to achieve positive working relationship with employees.Moreover, increasing customer demand for care in quality of service is highlighting the critical role played employees, thereby leading to customer satisfaction (Bitner 1990; Martinez Tur 2011; and Shemwell 1998). The increasing of accommodation and service in hospitality demand many services to fill up this need of tourism growth. Wosfold (1898) found that manager in the hospitality industry had awareness of participative style of leadership, but were more inclined to use autocratic approach. On another hand, Hsu \& Gregory (1995) identified the competencies need for an entry level hospitality manager from the industry viewpoint and that human-relations skills such as communication and leadership skills as perceived the majority important and should receive extra recognition in the future. Specially, Chung-Herrera, Enz, \&Lankau (2003) found the future based on eight factors of competency model for grooming a future hospitality leader, which is the world most models adapted of 
leadership competency in hostility which result was surveyed from 137 senior level managers in America. Surprisingly, self-management is the highest rating required for hospitality managers. Followed by competencies on strategic positioning, implementation, critical thinking, communication, interpersonal, leadership, and the last one is industry knowledge. Some scholars may argue that the required competencies have many different categories from different areas of the study.

\section{Methodology}

This research study is conduct based on a mixed method approach. Therefore, both of quantitative and qualitative research will be adopted in this research design. There are several reasons that researcher use mixed method models to study because in some of the previous studies related to competencies in hospitality industries, they preferred conduct only one research design. Mixed-method will enable to get data much richer and deeper from the respondent. It can gain perspective from different types of data or different levels within study.By using mixed method model of Creswell (2009) is employed. There were three types of population in this research which consist of high level managers, middle managers and staffs who working in five-star hotel in Phnom Penh Cambodia by conducting into two phase as below:

The first phase conducted the quantitative research by developed the questionnaire to survey the required competencies list and to reveal any new competencies criteria. In fact, the employees working in three five-star hotels in Phnom Penh are the target to participate in this research, but two out of three five-star hotels in Phnom Penh was the limitation to conduct a survey whereas the other hotel was prevented from taking part in the survey owing to administration policies. The groups of respondents are 373 sample size were selected from Middle Departments from the two five-star hotels: (1) Finance, (2) Front Office, (3) Housekeeping, (4) Spa, (5) Sport Club, (6) Food and Beverages Service, (7) Food and Beverage Kitchen, (8) Sale and Marketing, (9) Engineering, (10) Human Resource Department and (11) Executive Department.

In the second phase, the researcher is adapted the semi-structure interview by followed Behavioral Event Interview Outline (BEIs),(Spencer \& Spencer, 1993)with ten middle managers and two high level managers totally twelve participants who are used purposive, convenience, and snowball sampling. The reliability of the questionnaire is determined so as to ensure that the responses collected through the instrument are reliable and consistent. After the questionnaire are revised and verified again with the appropriateness of translation, a pilot study of the questionnaire is conducted by 30 staffs working in five-star hotels in Phnom Penh who are not in the sample group. The reliability value is calculated by using Coefficient Cronbach's alpha in order to ensure whether there is internal consistency within the items.The Alpha coefficient ( $\square$ ) of required competencies were respectively 0.76. Brotherton (2008) defined that ethic is not just an issue associated with the implementation of the research design in term of collecting data, but to be taken into the consideration throughout all the stages in the process, not only to ensure that dignity, rights and welfare of any human participants are protected but also that the work is designed and implemented in an hosted manner.

After finding the result of the required competencies for success of the middle managers 
being perceived by employees working in five-star hotel in Phnom Penh by doing survey in the manner of number and percentages, the semi-structure interview is utilized to response of the second objective. After receiving the data, a qualitative content analysis method including transcribing, coding and interpretation are applied in order to figure out the required competencies for success of middle managers in five-star hotels in Phnom Penh. Based on Bryman, (2012) identified that content analysis is a very transparent research method. The coding scheme and sampling procedures can be clearly set out so that replications and follow-up studies are feasible. It is this transparency that often causes content analysis to be referred to an objective method analysis. Above all, the second main objective is deeply analyzed from result of primary and secondary data for providing some recommendations to adjust or develop to contribute to hotels' development.

\section{Conclusion}

The researcher hopes that after findings of the current study will be able to contribute to middle managers, subordinates, high level managers and any interested readers or researchers in the field of competencies as thoroughly following (1) the middle managers will be able to aware of their required competencies as a result they might be encouraged to develop or transform their management behavior. Moreover, they may increase their work commitment and motivation which lead to high productivities, particularly reduction of turnover which is a predictor of time wasting and expenditure on new recruitment and training; (2) the findings will shed some light on the knowledge of competencies for subordinates in order to help subordinates to see the capacities or roles necessary for successful and efficient middle managers, which might create a good relationship with their colleagues on job satisfaction; (3) at the end of the research findings, recommendation on the dimensions of required competencies will be provided. Thus, the high level managers will enable to take into consideration or they can adapt the model in order to make an evaluation on the competencies of employees as a part of human resource management to recruit highly potential and qualified candidates in their profession; and (4) the findings of this study are expected to comprise empirical data for the study of competencies in Cambodian context, and expand the knowledge useful information to those who are interested in the field of competencies.

\section{Acknowledgements}

The author would like to highly acknowledge the grant support of Her Royal Highness Princess Maha Chakri Sirindhorn and the steering committee of the project of royal contribution in education to the Kingdom of Cambodia. More than that, he wants to offer his sincere appreciation to Asst. Prof. Dr. Patchanee Tharaseina, Dean of Graduate School of Public Administration, Burapha University, Thailand. More importantly, author would like to take this opportunity to express his immense gratitude to Dr. Thanawat Pimoljinda, principal adviser and Dr. Ritthikorn Siriprasertchok, co-adviser, for their indispensable part of help, professional guidance and continuous encouragement.

\section{References}

(1) Blayney, C. (2009). Management Competencies: Are they related to hotel performance? International Journal of 
Management and Marketing Research.2(1), 59-

71.

(2) Cheang, V. (2010). Tourism Development in Cambodia: Opportunities for Japanese Company. The Asia Pacific Journal of Tourism Research, 4-41.

(3) Chung-Herrera, B.G., Enz, C.A., \&Lankau, M.J. (2003). Grooming Future Hospitality Leaders: A Competencies model. Cornell and Restaurant Administration Quarterly, Jun 2003, 17-25.

(4) Creswell, J. W. (2009). Research design: Qualitative, quantitative, and mixed method approaches $\left(3^{\text {rd }}\right.$ ed.). Thousand Oaks, CA: Sage.

(5) McClelland, D. (1973). Testing for competence rather than for "intelligence". American Psychologist, 28(1), 1-14.

(6) Ministry of Tourism of Cambodia (MOT), (2013).Accommodation in Phnom Penh,

a. http://www.tourismcambodia.org, Retrieved on January 10, 2013.

(7) Oslen, M. (1990), Macro Forces Driving Change into the New MillenniumMajorChallenges for the Hospitality Professional. International Journal of Hospitality Management, 18(4), 371-385.

(8) Spencer, L.M ., \& Spencer, S.M. (1993). Competence at work: Models for superior performance. New York: John Wiley \& Sons.

(9) Tas, R. (1988). Teaching future managers. Cornell Hotel and Restaurant Administration Quarterly, 29(2), 41-43. Retrieve from International Journal of Management and Marketing Research (2009). Vol. 2 (1).

(10) Worsfold, P. (1989). Leadership and management effectiveness in the hospitality industry.International Journal of Hospitality Management, 8(2), 145-155. 